\title{
Pemodelan Matematika SEIR Penyebaran Penyakit Pneumonia pada Balita dengan Pengaruh Vaksinasi di Kota Makassar
}

\author{
Syafruddin Side ${ }^{1, a)}$, Wahidah Sanusi ${ }^{1, b)}$, dan Nurul Aulia Bohari ${ }^{1, c)}$ \\ ${ }^{1}$ Jurusan Matematika, Fakultas Matematika dan Ilmu Pengetahuan Alam \\ Universitas Negeri Makassar \\ a) syafruddinside@yahoo.com \\ b) wahidah.sanusi@unm.ac.id \\ c)auliabohari@gmail.com
}

\begin{abstract}
Abstrak. Penelitian ini bertujuan untuk membangun model penyebaran penyakit pneumonia pada balita tipe SEIR (Susceptible- Exposed-Infected-Recovered-), menganalisis model, dan menentukan proporsi minimum vaksinasi. Data yang digunakan adalah data jumlah penderita pneumonia pada balita di Kota Makassar tahun 2019. Hasil penelitian diperoleh model matematika SEIR penyakit pneumonia dalam bentuk sistem persamaan diferensial biasa; titik keseimbangan bebas kecanduan dan titik keseimbangan kecanduan yang keduanya bersifat stabil; bilangan reproduksi dasar untuk simulasi tanpa vaksinasi lebih besar dari 1 yang artinya penyakit masih tetap ada dalam populasi, sedangkan bilangan reproduksi dasar untuk simulasi dengan vasksinasi kurang dari 1 yang artinya penyakit akan menghilang dan tidak meluas dari populasi.
\end{abstract}

Kata Kunci: Titik Ekuilibrium, Bilangan Reproduksi Dasar, Pneumonia, Model SEIR.

\begin{abstract}
This study aims to build a model of the spread of pneumonia in SEIR (Susceptible-ExposedInfected-Recovered) toddlers, analyze the model, and determine the minimum proportion of vaccinations. The data used are data on the number of pneumonia sufferers in toddlers in Makassar City in 2019.The results obtained by the SEIR mathematical model of pneumonia in the form of ordinary differential equation systems; addiction free balance points and addiction balance points which are both stable; basic reproduction numbers for simulations without vaccination greater than 1, which means that the disease still exists in the population, while basic reproduction numbers for simulations with vasksination less than 1 , which means the disease will disappear and not spread from the population.
\end{abstract}

Keywords: Equilibrium Points, Basic Reproductive Numbers, Pneumonia, SEIR Model.

\section{PENDAHULUAN}

Bidang matematika turut memberikan peranan dalam menganalisis dan memodelkan suatu peristiwa atau permasalahan (Ihsan, Side, dan Wulandari, 2020). Pemodelan matematika merupakan suatu proses merepresentasikan dan menjelaskan permasalahan pada dunia nyata ke dalam pernyataan matematis (Side \& Rangkuti, 2015).

Model matematika merupakan salah satu alat yang dapat membantu mempermudah penyelesaian masalah dalam kehidupan nyata (Syam, Side, \& Said, 2020). Model matematika adalah hubungan antara komponen-komponen dalam suatu masalah yang dirumuskan dalam suatu persamaan matematik yang memuat komponen-kompenen itu sebagai variabelnya (Side \& Rangkuti, 2015). 
Model matematika dibuat berdasarkan asumsi-asumsi. Model matematika yang dibentuk akan dianalisa, agar model yang dibuat representatif terhadap permasalahan yang dibahas (Side, Zaki \& Sari, 2018). Banyak permasalahan yang timbul dari berbagai bidang ilmu, misalnya kesehatan, kimia, bilogi, dan lain-lain yang dapat dibuat model matematikanya. Dalam berbagai bidang ilmu yang dapat dibuat model matematika salah satunya dalam bidang kesehatan yaitu model matematika dalam fenomena penyebaran penyakit pneumonia.

Pneumonia adalah proses infeksi akut yang mengenai jaringan paru-paru (alveoli). Terjadinya pneumonia pada anak seringkali bersamaan dengan proses infeksi akut pada bronkus (biasa disebut bronchopneumonia). Gejala penyakit ini berupa napas cepat dan napas sesak, karena paru meradang secara mendadak. Ketika seseorang menderita pneumonia, maka alveoli akan dipenuhi nanah dan cairan yang membuat kesakitan saat bernapas dan asupan oksigen yang dihirup terbatas Pneumonia sering terjadi pada anak usia bawah lima tahun dan penyebab utama kematian dari 2 juta anak tiap tahun yang terjadi di negara berkembang (Depkes RI, 2002; Ruslaeni, 2010).

Salah satu cara untuk mencegah penyakit ini adalah dengan vaksinasi. Vaksinasi diberikan dengan memberikan vaksin yaitu bahan antigenik yang digunakan untuk menghasilkan kekebalan aktif terhadap suatu penyakit, sehingga dapat mencegah atau mengurangi pengaruh infeksi oleh organisme ke dalam tubuh seseorang dengan tujuan untuk mmberikan kekebalan terhadap penyakit.

Beberapa peneliti telah mengkaji model SEIR pada penularan penyakit dengan pengaruh vaksinasi. Diantaranya penelitian yang dilakukan oleh Ansar tahun 2018 dengan judul penelitian "Pemodelan Matematika SIRS dengan pengaruh vaksinasi pada penyebaran penyakit malaria", Ermilatni tahun 2016 dengan judul penelitian "Pemodelan Matematika SEIR pada penyebaran penyakit campak dengan vaksinasi" dan penelitian yang dilakukan oleh Rosdiana tahun 2015 dengan judul penelitian "Pemodelan matematika SIR dengan vaksinasi pada penyebaran penyakit hepatitis B (Studi Kasus Provinsi Sulawesi Selatan)”. Belum ada peneliti yang membuat dan menerapkan model matematika SEIR pada penyakit pneumonia. Maka dari itu penulis tertarik untuk mengkaji masalah penyebaran penyakit pneumonia menggunakan model SEIR untuk kasus pneumonia pada balita dengan pengaruh vaksinasi di Kota Makassar.

\section{KAJIAN PUSTAKA}

\section{Persamaan Diferensial}

Persamaan diferensial banyak muncul sebagai persamaan yang sangat penting dalam matematika terapan, karena banyak hukum dan hubungan fisis secara matematis muncul dalam bentuk persamaan ini. Secara umum persamaan diferensial didefinisikan

Definisi 1. Persamaan Diferensial (Sugiyarto, 2014)

Persamaan diferensial adalah persamaan yang memuat turunan dari satu atau lebih variabel tak bebas terhadap satu atau lebih variabel bebas.

Persaman Diferensial biasa adalah suatu bentuk persamaan yang melibatkan turunan dari satu atau lebih variabel tak bebas terhadap satu variabel bebas (Lestari, 2013). Contoh persamaan diferensial biasa disajikan pada persamaan (1).

$$
4 \frac{d y}{d x}-5 y=1
$$




\section{Titik Ekuilibrium dan Kestabilannya}

Misalkan diberikan persamaan diferensial sebagaimana persamaan (2).

$$
\frac{d x}{d t}=f(x), x \in R^{n}
$$

Titik $x^{*}$ disebut titik tetap jika memenuhi $f\left(x^{*}\right)=0$. Titik tetap merupakan penyelesaian yang bergantung pada $t$ (konstan terhadap waktu). Titik tetap disebut juga titik kritis atau titik keseimbangan. Untuk selanjutnya digunakan istilah titik tetap (Grimshaw, 1990).

\section{Model SEIR}

Model matematika SEIR (Suspected-Exposed-Infected-Recovered) yang merupakan perluasan dari model epidemi SIR (Suspected-Infected-Recovered) yang dikemukakan oleh Kermack dan McKendrick pada tahun 1927, dimana SIR dibagi menjadi tiga kelompok yaitu kelompok individu yang rentan (sehat tetapi dapat terinfeksi penyakit (Suspected), kelompok individu yang terinfeksi dan dapat sembuh dari penyakit (Infected), dan kelompok individu yang sembuh dan kebal dari penyakit (Recovered). setiap individu hanya akan berada dalam satu kelompok saja pada satu waktu. Maka keempat kelompok ini dapat didefinisikan dalam bentuk matematika sebagaimana pada persamaan (3).

$$
S(t)+E(t)+I(t)+R(t)=N
$$

Hubungan keempat kelompok ini dapat disajikan ke dalam Gambar 1.

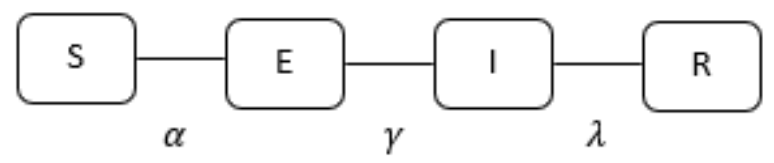

GAMBAR 1. Diagram Transfer secara umum

Parameter $\alpha$ merupakan laju transmisi penyakit dari individu susceptible ke individu rentan (exposed). Parameter $\gamma$ diberikan sebagai laju perpindahan dari keadaan Exposed menjadi keadaan Infected. Sedangkan $\lambda$ mendeskripsikan transmisi antara Infected dan Recovered (Side \& Rangkuti, 2015).

\section{Kriteria Kestabilan Routh-Hurwits}

Permasalahan yang sering timbul dalam menentukan suatu tipe kestabilan sistem dengan menggunakan nilai eigen adalah ketika mencari akar persamaan karakteristik berorde tinggi. Oleh sebab itu, diperlukan suatu kriteria yang mampu menjamin nilai dari akar suatu persamaan karakteristik tersebut negative atau ada yang bernilai positif. Salah satu kriteria yang efektif untuk menguji kestabilan sistem adalah kriteria routh-hurwitz dapat dilihat pada Tabel 1 .

TABEL 1. Rount-Hurwitz

\begin{tabular}{ccccccc}
\hline$s^{n}$ & $a_{0}$ & $a_{2}$ & $a_{4}$ & $a_{6}$ & $\ldots$ & $a_{n-1}$ \\
\hline$s^{n-1}$ & $a_{1}$ & $a_{3}$ & $a_{5}$ & $a_{7}$ & $\ldots$ & $a_{n}$ \\
$s^{n-2}$ & $b_{1}$ & $b_{2}$ & $b_{3}$ & $b_{4}$ & $\ldots$ & $b_{n}$ \\
$s^{n-3}$ & $c_{1}$ & $c_{2}$ & $c_{3}$ & $c_{4}$ & $\ldots$ & $c_{n}$ \\
$\vdots$ & $\vdots$ & $\vdots$ & & & & \\
$s^{0}$ & & & & & & \\
\hline
\end{tabular}

(Wahab \& Subiantoto, 2004) 


\section{Bilangan Reproduksi Dasar}

Bilangan reproduksi dasar $\left(R_{0}\right)$ merupakan jumlah rata-rata kasus individu terinfeksi yang disebabkan oleh satu individu terinfeksi selama masa terinfeksinya dalam keseluruhan populasi rentan (Diekmann \& Heesterbeek, 2000).

Jika $R_{0}<1$ maka penyakit hanya menginfeksi kurang dari satu individu rentan sehingga kemungkinan penyakit akan hilang dari populasi. Jika $R_{0}>1$ maka individu yang terinfeksi akan menginfeksi lebih dari satu individu yang rentan. Jika $R_{0}=1$ maka individu yang terinfeksi akan menularkan tepat kepada satu individu.

\section{Pneumonia}

Pneumonia adalah proses infeksi akut yang mengenai jaringan paru-paru (alveoli). Terjadinya pneumonia pada anak seringkali bersamaan dengan proses infeksi akut pada bronkus (biasa disebut bronchopneumonia). Gejala penyakit ini berupa napas cepat dan napas sesak, karena paru meradang secara mendadak. Batas napas cepat adalah frekuensi pernapasan sebanyak 60 kali permenit pada anak usia $<2$ bulan, 50 kali per menit atau lebih pada anak usia 2 bulan sampai kurang dari 1 tahun, dan 40 kali permenit atau lebih pada anak usia 1 tahun sampai kurang dari 5 tahun.

\section{Vaksinasi}

Vaksinasi merupakan penyuntikan mikroba mati atau lemah untuk merangsang system kekebalan tubuh terhadap mikroba tersebut, sehingga tubuh menghasilkan antibodi untuk mencegah penyakit. Vaksinasi bekerja dengan merangsang system kekebalan tubuh, melawan penyakit dengan sistem alami tubuh. Sistem kekebalan tubuh yang sehat mampu mengenali, menyerang bakteri dan virus serta menghasilkan zat (antibodi) untuk menghancurkan atau menonaktifkannya.

\section{METODE PENELITIAN}

Metode yang digunakan dalam penelitian ini adalah studi literature dengan data populasi balita yang menderita penyakit pneumonia dari Dinas Kesehatan Kota Makassar. Langkah pertama yang dilakukan adalah membangun model matematika dengan model SEIR yaitu dengan mengumpulkan informasi dan data untuk menentukan batasan asumsi dan parameter model SEIR, kemudian menentukan diagram alir dari model SEIR berdasarkan batasan asumsi dan parameter yang telah dibuat. Selanjutnya menganalisis kestabilan model SEIR yaitu dengan menentukan titik tetap model SEIR yang telah dibuat kemudian menganalisis kestabilan titik tetap bebas penyakit dan titik tetap endemic penyakit berdasarkan nilai eigen yang diperoleh dari metode linearisasi dan menentukan bilangan reproduksi dasar model SEIR. Langkah terakhir adalah mengetahui pengaruh vaksinasi menggunakan simulasi dari model SEIR yaitu dengan menentukan nilai awal yang diperoleh pada hasil pemodelan SEIR dan simulasi program dengan nilai-nilai yang telah diperoleh dari hasil simulasi model SEIR.

\section{HASIL PENELITIAN}

\section{Model Matematika SEIR Penyebaran Penyakit Pneumonia pada Balita}

Dalam penelitian ini terdapat beberapa asumsi yang digunakan untuk memodelkan penyebaran penyakit pneumonia pada balita, yaitu: 
1. Terdapat kelahiran dan kematian dalam suatu populasi

2. Tidak terdapat migrasi

3. Setiap individu yang lahir akan menjadi rentan

4. Setiap individu yang terdeteksi akan menjadi terinfeksi

5. Masa inkubasi penyakit pneumonia (singkat) 7-14 hari

6. Penyakit berbahaya, jika terinfeksi dapat menimbulkan kematian

7. Individu yang rentan jika di vaksinasi akan kebal terhadap penyakit

8. Individu yang telah sembuh akan kebal terhadap penyakit pneumonia dan tidak menjadi rentan kembali

Berdasarkan asumsi maka diperoleh model SEIR pada penyebaran penyakit Pneumonia pada balita dalam bentuk diagram transfer yang dapat dilihat pada Gambar 2.

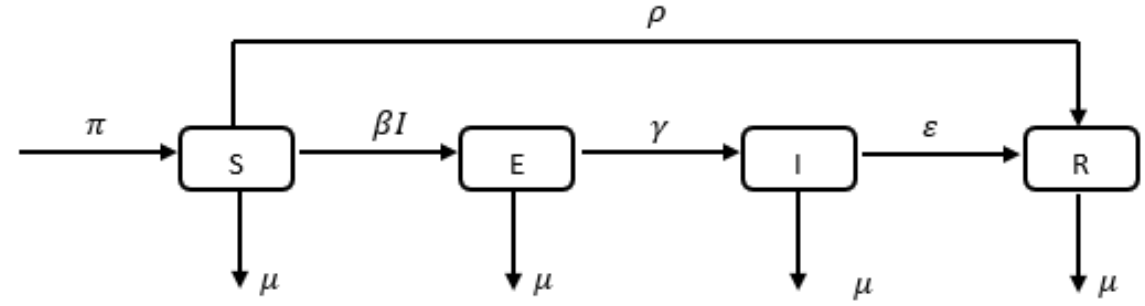

GAMBAR 2. Diagram Transfer Model Matematika SEIR Penyebaran Penyakit Pneumonia pada Balita

Adapun penjelasan dari Gambar 1 dapat dilihat pada Tabel 2.

TABEL 2. Penjelasan Variabel/Parameter

\begin{tabular}{cl}
\hline Variabel/Parameter & \multicolumn{1}{c}{ Keterangan } \\
\hline $\mathrm{S}(\mathrm{t})$ & Jumlah Individu yang rentan (sehat tetapi dapat terinfeksi) \\
$\mathrm{E}(\mathrm{t})$ & Jumlah individu yang terdeteksi tetapi belum terinfeksi \\
$\mathrm{I}(\mathrm{t})$ & Jumlah individu yang terinfeksi (telah menjadi pneumonia) \\
$\mathrm{R}(\mathrm{t})$ & Jan dapat menularkan penyakit \\
$\pi$ & Laju kelahiran \\
$\mu$ & Laju Kematian \\
$\beta i$ & Laju Infeksi dari individu rentan menjadi individu laten karena \\
& adanya kontak antara individu rentan dengan individu \\
$\gamma$ & terinfeksi \\
$\varepsilon$ & Laju individu yang terinfeksi \\
$\rho$ & Laju Kesembuhan dari setiap individu terinfeksi \\
\hline
\end{tabular}

Berdasarkan asumsi dan hubungan antara variabel dan parameter pada Gambar 1 dapat dijelaskan pada sistem persamaan (4).

$$
\begin{aligned}
& \frac{d S}{d t}=\pi(1-\rho) N-\left(\frac{\beta I}{N}+\mu+\rho\right) S \\
& \frac{d E}{d t}=\frac{\beta I S}{N}-(\mu+\gamma) E \\
& \frac{d I}{d t}=\gamma E-(\mu+\varepsilon) I \\
& \frac{d R}{d t}=\varepsilon I+\rho S-\mu R
\end{aligned}
$$

dengan $\mathrm{N} \neq(\mathrm{S}(\mathrm{t})+\mathrm{E}(\mathrm{t})+\mathrm{I}(\mathrm{t})+\mathrm{R}(\mathrm{t}))$ adalah total populasi. 
Untuk menyederhanakan sistem persamaan (4), dapat digunakan penskalaan dengan menyederhanakan notasi, dimisalkan

$$
\begin{aligned}
s & =\frac{S}{N} \\
e & =\frac{E}{N} \\
i & =\frac{I}{N} \\
r & =\frac{R}{N}
\end{aligned}
$$

Sehingga sistem persamaan (4) dapat disederhanakan seperti sistem persamaan (5).

$$
\begin{aligned}
& \frac{d s}{d t}=\pi(1-\rho)-(\beta i+\mu+\rho) s \\
& \frac{d e}{d t}=\beta i s-(\gamma+\mu) e \\
& \frac{d i}{d t}=\gamma e-(\mu+\varepsilon) i \\
& \frac{d r}{d t}=\varepsilon i+\rho s-\mu r
\end{aligned}
$$

\section{Analisis Model Matematika SEIR Penyebaran Penyakit Pneumonia pada Balita}

Titik Ekuilibrium

Titik ekuilibrium terjadi pada saat $\left(\frac{d S}{d t}, \frac{d E}{d t}, \frac{d I}{d t}, \frac{d R}{d t}\right)=(0,0,0,0)$. Sistem persamaan (5) memiliki dua titik ekuilibrium, yaitu titik ekuilibrium bebas penyakit yang dinotasikan dengan $E_{0}$ dan titik ekuilibrium endemik yang dinotasikan dengan $E_{1}$. Titik ekuilibrium bebas penyakit diperoleh dengan asumsi bahwa $e=0$ dan $i=0$ yang berarti tidak ada individu yang terinfeksi dan menularkan penyakit. Berdasarkan sistem persamaan (5), diperoleh titik ekuilibrium bebas penyakit $E_{0}=(s, e, i, r)=\left(\frac{\pi(1-\rho)}{\mu+\rho}, 0,0, \frac{\rho s}{\mu}\right)$. Untuk mengetahui titik ekuilibrium endemik, misalkan $E_{1}\left(s^{*}, e^{*}, i^{*}, r^{*}\right)$ maka diasumsikan $s^{*}, e^{*}, i^{*}, r^{*} \neq 0$, sehingga diperoleh $E_{1}=$ $\left(s^{*}, e^{*}, i^{*}, r^{*}\right)$ dimana $s^{*}=\frac{\pi(1-\rho)}{(\beta+\mu+\rho)}, \quad e^{*}=\frac{\beta \pi(1-\rho)}{(\beta+\mu+\rho)(\gamma+\mu)}, i^{*}=\frac{\beta \pi \gamma(1-\rho)}{(\beta+\mu+\rho)(\gamma+\mu)(\mu+\varepsilon)}, \quad$ dan $r^{*}=$ $\frac{\beta \pi \gamma(1-\rho)+\rho(\pi(1-\rho)}{(\beta+\mu+\rho)(\gamma+\mu)(\mu+\varepsilon)(\beta+\mu+\rho)(\mu)}$

\section{Penentuan jenis kestabilan titik ekuilibrium}

Jenis kestabilan titik ekuilibrium bebas penyakit $E_{0}$ diperoleh dengan melakukan pelinearan pada sistem persamaan (5) disekitar $E_{0}$, sehingga diperoleh matriks Jacobian sebagai berikut.

$$
\mathrm{JE}_{0}=\left[\begin{array}{cccc}
-(\mu+\rho) & 0 & -\beta \mathrm{s} & 0 \\
0 & -(\gamma+\mu) & \beta \mathrm{s} & 0 \\
0 & \gamma & -(\mu+\varepsilon) & 0 \\
\rho & 0 & \varepsilon & -\mu
\end{array}\right]
$$

Untuk mengetahui kestabilan $E_{0}$, maka dicari nilai eigen dari matiks $J\left(E_{0}\right)$ dengan menentukan $\operatorname{det}\left(J\left(E_{0}\right)-\lambda \mathrm{I}\right)=0$, dimana $\lambda$ adalah nilai eigen dan I adalah matriks identitas.

$$
\begin{gathered}
\left(\lambda\left[\begin{array}{llll}
1 & 0 & 0 & 0 \\
0 & 1 & 0 & 0 \\
0 & 0 & 1 & 0 \\
0 & 0 & 0 & 1
\end{array}\right]-\left[\begin{array}{cccc}
-(\mu+\rho) & 0 & -\beta s & 0 \\
0 & -(\gamma+\mu) & \beta s & 0 \\
0 & \gamma & -(\mu+\varepsilon) & 0 \\
\rho & 0 & \varepsilon & -\mu
\end{array}\right]\right)=0 \\
\operatorname{det}\left(\left[\begin{array}{llll}
\lambda & 0 & 0 & 0 \\
0 & \lambda & 0 & 0 \\
0 & 0 & \lambda & 0 \\
0 & 0 & 0 & \lambda
\end{array}\right]-\left[\begin{array}{cccc}
-(\mu+\rho) & 0 & -\beta s & 0 \\
0 & -(\gamma+\mu) & \beta s & 0 \\
0 & \gamma & -(\mu+\varepsilon) & 0 \\
\rho & 0 & \varepsilon & -\mu
\end{array}\right]\right)=0
\end{gathered}
$$




$$
\operatorname{det}\left(\left[\begin{array}{cccc}
(\lambda+\mu+\rho) & 0 & \beta \mathrm{s} & 0 \\
0 & (\lambda+\gamma+\mu) & -\beta \mathrm{s} & 0 \\
0 & -\gamma & (\lambda+\mu+\varepsilon) & 0 \\
-\rho & 0 & -\varepsilon & (\lambda+\mu)
\end{array}\right]\right)=0
$$

Diperoleh nilai eigen yaitu a,b,c,d dengan $a=4 \mu+\rho+\gamma+\varepsilon, b=6 \mu^{2}+3 \mu \rho+3 \mu \gamma+3 \mu \varepsilon+$ $\rho \varepsilon+\rho \gamma+\gamma \varepsilon+\frac{\pi \beta \rho \gamma}{\mu+\rho}-\frac{\pi \beta \gamma}{\mu+\rho}, c=4 \mu^{3}+3 \mu^{2} \rho+3 \mu^{2} \gamma+3 \mu^{2} \rho+2 \mu \rho \varepsilon+2 \mu \gamma \varepsilon+2 \mu \rho \gamma+$ $\rho \gamma \varepsilon+\frac{2 \mu \pi \beta \rho \gamma}{\mu+\rho}-\frac{2 \mu \pi \beta \gamma}{\mu+\rho}+\frac{\mu \beta \rho^{2} \gamma}{\mu+\rho}-\frac{\pi \beta \rho \gamma}{\mu+\rho}, d=\mu^{4}+\mu^{3} \rho+\mu^{3} \gamma+\mu^{3} \varepsilon+\mu^{2} \rho \gamma+\mu^{2} \rho \varepsilon+\mu^{2} \gamma \varepsilon+$ $\mu \rho \gamma \varepsilon+\mu \pi \beta \rho \gamma-\mu \pi \beta \gamma$. Karena semua suku positif maka sistem tersebut stabil, maka syarat perlu dan cukup untuk stabil terpenuhi. Sistem stabil $d>0$ dimana parameternya $\epsilon(0,1)$.Selanjutnya menentukan jenis kestabilan titik ekuilibrium endemik $E_{1}$ dengan cara yang sama seperti menentukan jenis kestabilan titik ekuilibrium bebas penyakit $E_{0}$. Sehingga diperoleh nilai eigen yaitu $a=4 \mu-\beta i^{*} \rho+\beta i^{*}+\rho+\gamma+\varepsilon, \quad b=6 \mu^{2}-3 \mu \beta i^{*} \rho+3 \mu \beta i^{*}+3 \mu \varepsilon+$ $3 \mu \gamma+3 \mu \rho-\beta i^{*} \rho \varepsilon-\beta i^{*} \rho \gamma+\beta i^{*} \varepsilon+\beta i^{*} \gamma-\beta s^{*} \gamma+\beta \rho s^{*} \gamma+\gamma \varepsilon+\rho \varepsilon+\rho, c=4 \mu^{3}-$ $3 \mu^{2} \beta i^{*} \rho+3 \mu^{2} \beta i^{*}+3 \mu^{2} \varepsilon+3 \mu^{2} \gamma+3 \mu^{2} \rho-2 \mu \beta i^{*} \rho \varepsilon-2 \mu \beta i^{*} \rho \gamma+2 \mu \beta i^{*} \varepsilon+2 \mu \beta i^{*} \gamma-$ $2 \mu \beta s^{*} \gamma+2 \mu \gamma \varepsilon+2 \mu \rho \varepsilon+2 \mu \rho \gamma+2 \mu \beta \rho s^{*} \gamma-\beta i^{*} \rho \gamma \varepsilon+\beta i^{*} \gamma \varepsilon-\beta s^{*} \rho \gamma+\rho \gamma \varepsilon+\beta \rho^{2} s^{*} \gamma$, $d=\mu^{4}-\mu^{3} \beta i^{*} \rho+\mu^{3} \beta i^{*}+\mu^{3} \rho+\mu^{3} \gamma+\mu^{3} \varepsilon-\mu^{2} \beta i^{*} \rho \varepsilon-\mu^{2} \beta i^{*} \rho \gamma+\mu^{2} \beta i^{*} \varepsilon+\mu^{2} \beta i^{*} \gamma-$ $\mu^{2} \beta s^{*} \gamma+\mu^{2} \gamma \varepsilon+\mu^{2} \rho \varepsilon+\mu^{2} \rho \gamma+\mu^{2} \beta \rho s^{*} \gamma-\mu \beta i^{*} \rho \gamma \varepsilon+\mu \beta i^{*} \gamma \varepsilon-\mu \beta s^{*} \rho \gamma+\mu \rho \gamma \varepsilon+$ $\mu \beta \rho^{2} s^{*} \gamma$. Polynomial orde empat mempunyai akar negatif pada bagian realnya jika dan hanya jika elemen-elemen dari kolom pertama pada tabel Rounth Hurwitz mempunyai tanda sama. Sehingga diperoleh $R_{0}>1$ maka titik setimbang endemik stabil asimtotik.

\section{Bilangan reproduksi dasar}

Bilangan reproduksi dasar diperoleh dengan menentukan nilai eigen dari matriks Jacobian dari suatu sistem persamaan (model) yang dihitung pada titik ekuilibrium bebas penyakit. Perhatikan persamaan (6).

$\mu^{4}+\mu^{3} \rho+\mu^{3} \gamma+\mu^{3} \varepsilon+\mu^{2} \rho \gamma+\mu^{2} \rho \varepsilon+\mu^{2} \gamma \varepsilon+\mu \rho \gamma \varepsilon+\mu \pi \beta \rho \gamma-\mu \pi \beta \gamma=0$

Nilai reproduksi dasar dari persamaan (6) diperoleh dari bagian konstannya sehingga diperoleh

$$
R_{0}=\frac{\mu \pi \beta \gamma}{\mu^{4}+\mu^{3} \rho+\mu^{3} \gamma+\mu^{3} \varepsilon+\mu^{2} \rho \gamma+\mu^{2} \rho \varepsilon+\mu^{2} \gamma \varepsilon+\mu \rho \gamma \varepsilon+\mu \pi \beta \rho \gamma}
$$

\section{Simulasi Model SEIR Penyebaran Penyakit Pneumonia}

TABEL 3. Data Awal

\begin{tabular}{cccc}
\hline \multirow{2}{*}{ Variabel } & \multicolumn{3}{c}{ Nilai Awal } \\
\cline { 2 - 4 }$S(0)$ & $\frac{40 \%}{146.990}$ & $\frac{46.990}{149725}$ & $\frac{46.990}{149.725}$ \\
\cline { 2 - 4 }$E(0)$ & $\frac{5.675}{149.725}$ & $\frac{5.675}{149.725}$ & $\frac{5.675}{149.725}$ \\
$I(0)$ & $\frac{574}{149.725}$ & $\frac{574}{149.725}$ & $\frac{574}{149.725}$ \\
$R(0)$ & $\frac{57}{149.725}$ & $\frac{287}{149.725}$ & $\frac{517}{149.725}$ \\
\hline
\end{tabular}




\section{Simulasi Model SEIR tanpa Vaksinasi}

Nilai-nilai parameter yang digunakan pada simulasi menggunakan nilai yang diasumsikan pada Tabel 4.

TABEL 4. Parameter Model SEIR Penyakit Pneumonia

\begin{tabular}{cc}
\hline Parameter & Nilai \\
\hline$\pi$ & 0,073 \\
$\pi$ & 0,073 \\
$\pi$ & 0,073 \\
$\gamma$ & 0,071 \\
$\beta$ & 1,449 \\
$\mu$ & 0,073 \\
$\mu$ & 0,073 \\
$\mu$ & 0,073 \\
$\varepsilon$ & 0,075 \\
$\rho$ & 0,000 \\
\hline
\end{tabular}

Jika nilai parameter ke sistem persamaan (5), diperoleh jika nilai R sebesar 10\%, 50\% dan $90 \%$ maka diperoleh nilai $R_{0}$ masing-masing adalah $R_{0}=8,756, R_{0}=6,242$, dan $R_{0}=4,854$. Hal ini berarti bahwa terdapat balita yang terkena penyakit pneumonia dalam suatu populasi yang tidak dicegah dengan vaksinasi memungkinkan terjadinya penularan dari satu individu ke individu lain. Sehingga dapat dikatakan penyakit pneumonia pada balita masih tetap ada dalam populasi. Simulasi model disajikan pada Gambar 3.

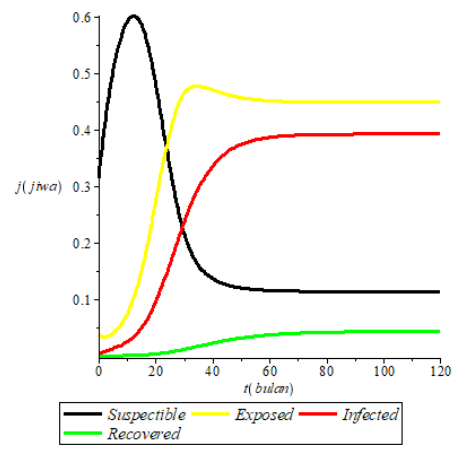

(a)

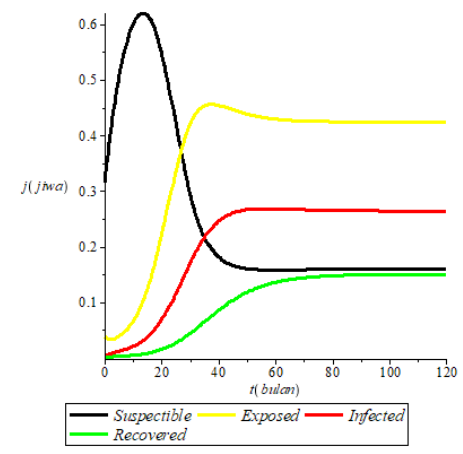

(b)

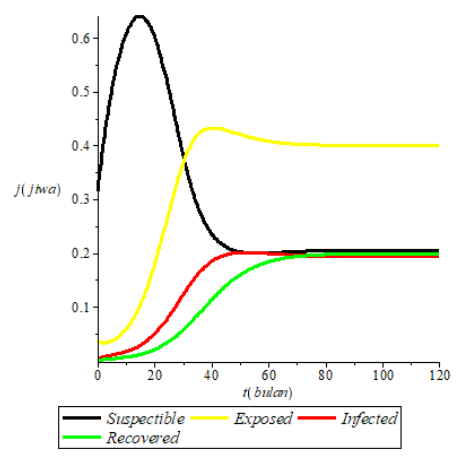

(c)

GAMBAR 3. Simulasi Model SEIR tanpa Vaksinasi

Gambar 3. bagian (a) merupakan hasil simulasi model SEIR dengan nilai $\mathrm{R}$ sebesar $10 \%$ tanpa Vaksinasi, bagian (b) merupakan hasil simulasi model SEIR dengan nilai R sebesar 50\% tanpa vaksinasi, dan bagian (c) merupakan hasil simulasi model SEIR dengan nilai R sebesar $90 \%$ tanpa vaksinasi. 


\section{Simulasi Model SEIR dengan vaksinasi}

Nilai-nilai parameter yang digunakan pada simulasi menggunakan nilai yang diasumsikan pada Tabel 5.

TABEL 5. Nilai Parameter Model SEIR penyakit pneumonia

\begin{tabular}{cccc}
\hline Parameter & Nilai Parameter 1 & Nilai Parameter 2 & Nilai Parameter 3 \\
\hline$\pi$ & 0,073 & 0,073 & 0,073 \\
$\mu$ & 0,073 & 0,073 & 0,073 \\
$\beta$ & 1,449 & 1,449 & 1,449 \\
$\gamma$ & 0,071 & 0,071 & 0,071 \\
$\varepsilon$ & 0,008 & 0,042 & 0,075 \\
$\rho$ & 0,100 & 0,500 & 0,900 \\
\hline
\end{tabular}

Jika nilai parameter ke sistem persamaan (5), diperoleh jika nilai R sebesar 10\%, dengan vaksinasi sebesar $10 \%, 50 \%$ dan $90 \%$ maka diperoleh nilai $R_{0}$ masing-masing adalah $R_{0}=2,704, R_{0}=$ 0,718 , dan $R_{0}=0,414$. Nilai $\mathrm{R}$ sebesar $50 \%$ dengan vaksinasi sebesar $10 \%, 50 \%$ dan $90 \%$ diperoleh nilai $R_{0}=2,086, R_{0}=0,569$, dan $R_{0}=0,329$. Nilai $\mathrm{R}$ sebesar $90 \%$ dengan vaksinasi sebesar $10 \%, 50 \%$ dan $90 \%$ diperoleh nilai $R_{0}=1,698, R_{0}=0,472$, dan $R_{0}=$ 0,274 . Hal ini berarti bahwa balita yang terkena penyakit pneumonia dalam suatu populasi yang diberi vaksinasi $10 \%$ tidak berhasil membuat penyakit hilang dari populasi sedangkan jika diberi vaksinasi sebesar $50 \%$ dan $90 \%$ penyakit akan menghilang dan tidak meluas dari populasi. Simulasi model disajikan pada Gambar 4.

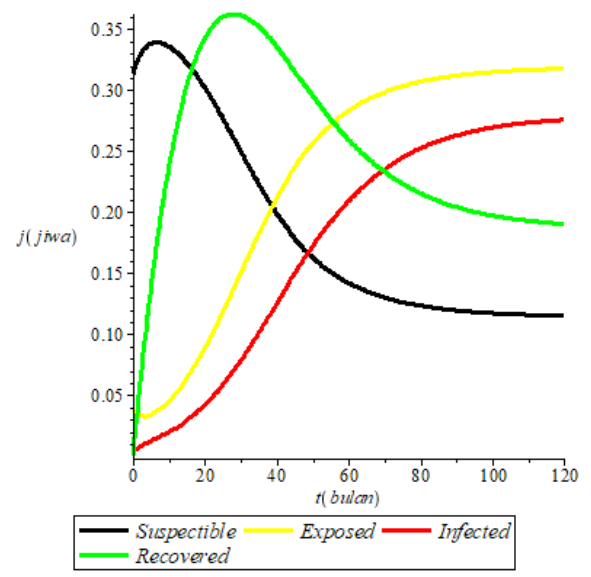

(a)

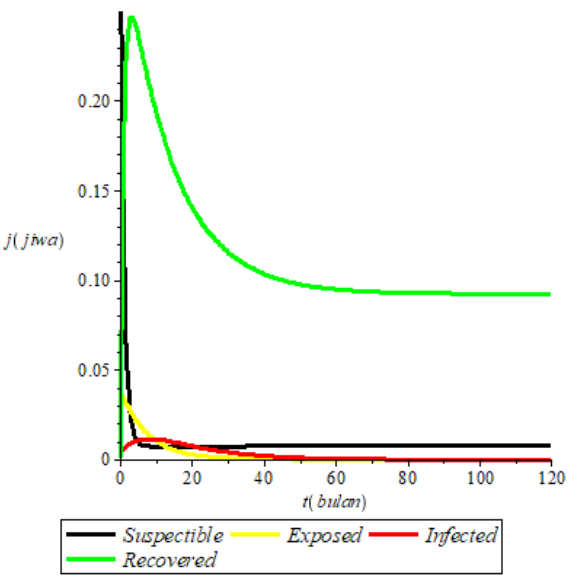

(c)

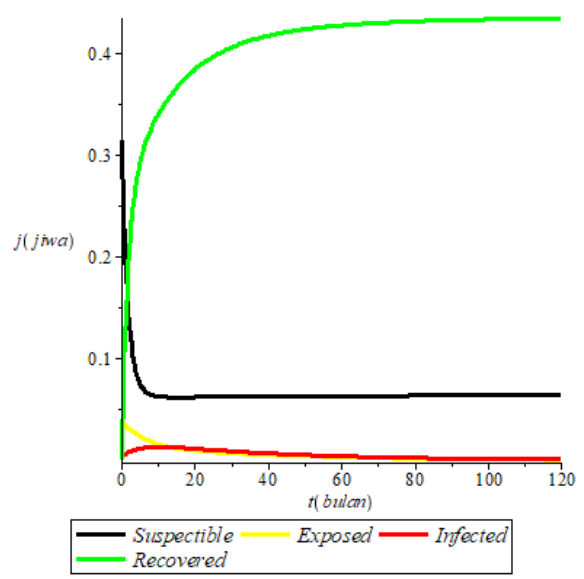

(b)

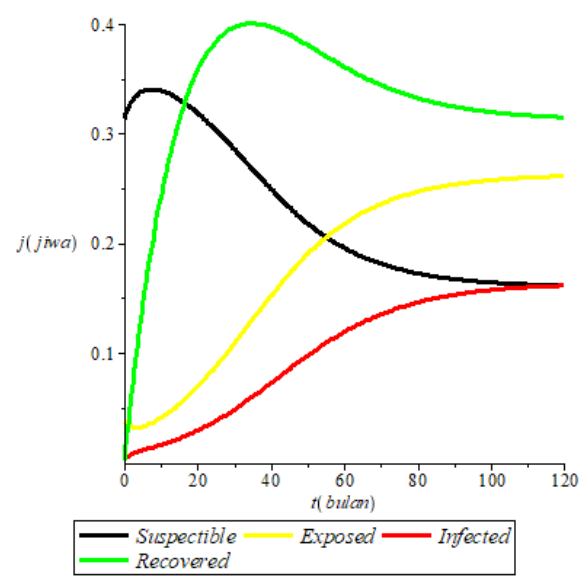

(d) 


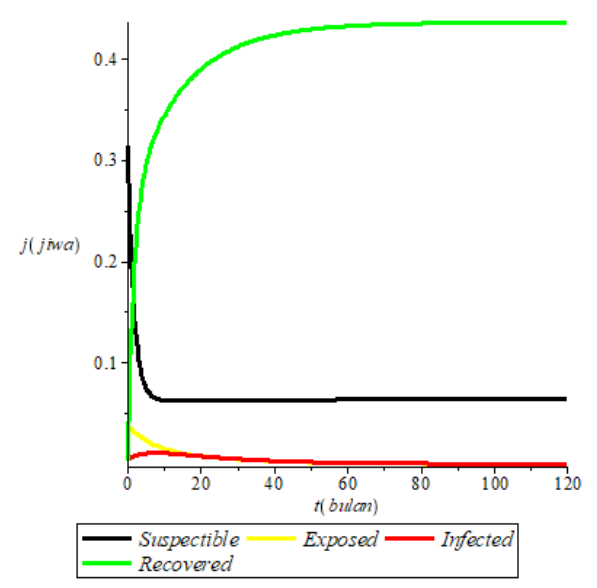

(e)

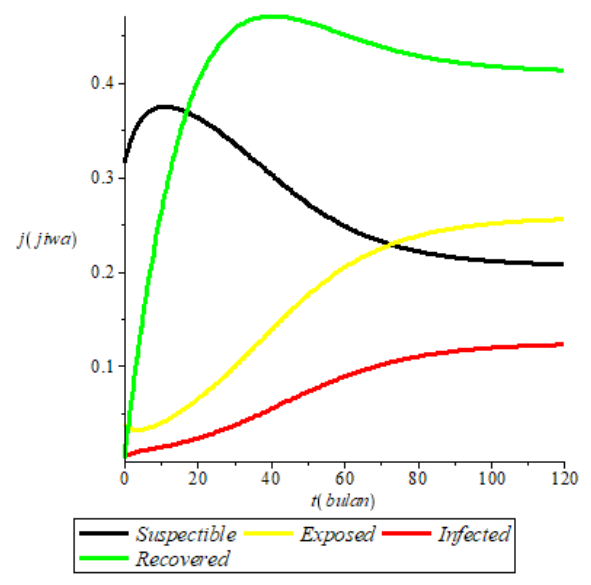

$(\mathrm{g})$

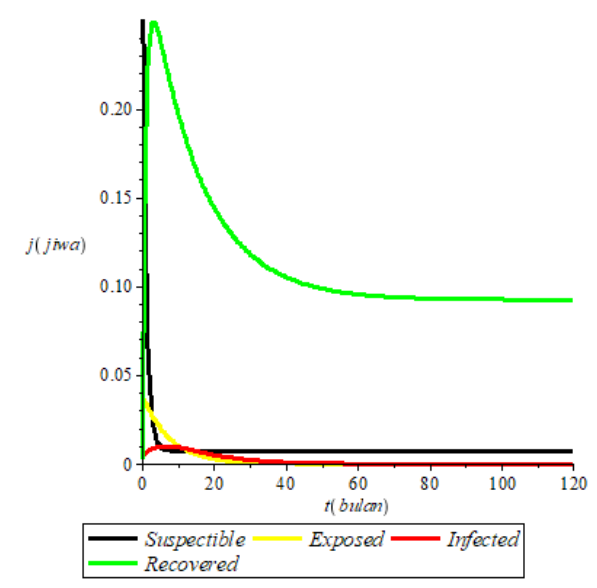

(f)

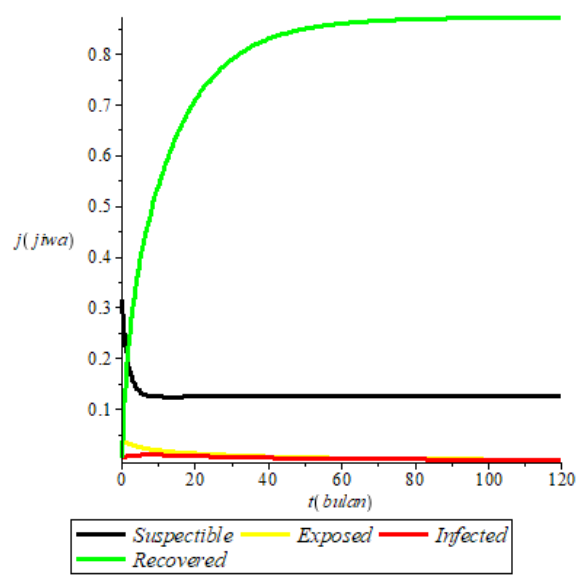

(h)

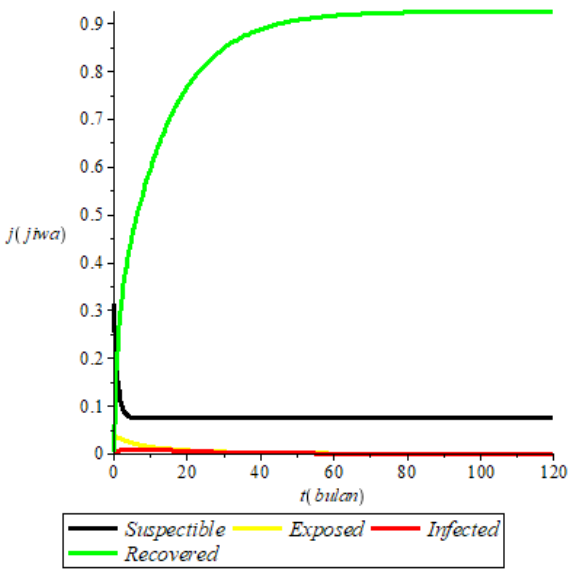

(i)

GAMBAR 4. Simulasi Model SEIR dengan Vaksinasi

Gambar 4. bagian (a) merupakan hasil simulasi model SEIR dengan nilai R sebesar 10\% dengan Vaksinasi $10 \%$, bagian (b) merupakan hasil simulasi model SEIR dengan nilai R sebesar $10 \%$ dengan vaksinasi 50\%, bagian (c) merupakan hasil simulasi model SEIR dengan nilai R sebesar $10 \%$ dengan vaksinasi 90\%, bagian (d) merupakan hasil simulasi model SEIR dengan nilai $\mathrm{R}$ sebesar 50\% dengan Vaksinasi 10\%, bagian (e) merupakan hasil simulasi model SEIR dengan nilai R sebesar $50 \%$ dengan vaksinasi 50\%, dan bagian (f) merupakan hasil simulasi model SEIR 
dengan nilai R sebesar 90\% dengan vaksinasi 90\%. bagian (g) merupakan hasil simulasi model SEIR dengan nilai R sebesar $90 \%$ dengan Vaksinasi 10\%, bagian (h) merupakan hasil simulasi model SEIR dengan nilai R sebesar $90 \%$ dengan vaksinasi 50\%, dan bagian (i) merupakan hasil simulasi model SEIR dengan nilai R sebesar 90\% dengan vaksinasi $90 \%$.

\section{KESIMPULAN}

Berdasarkan hasil penelitian yang telah di uraikan, diperoleh kesimpulan sebagai berikut:

1. Model Matematika SEIR pada penyebaran penyakit pneumonia pada balita dengan pengaruh vaksinasi di Kota Makassar dibangun dengan membuat asumsi-asumsi yaitu terdapat kelahiran dan kematian dalam suatu populasi, setiap individu yang terdeteksi akan menjadi terinfeksi, Individu yang rentan jika di vaksinasi akan kebal terhadap penyakit, individu yang telah sembuh akan kebal terhadap penyakit pneumonia dan tidak menjadi rentan kembali. Berdasarkan asumsi model pada penyebaran penyakit pneumonia pada balita dengan pengaruh vaksinasi berbentuk diagram transfer kemudian dibentuk menjadi persamaan differensial yaitu:

$$
\begin{aligned}
& \frac{d S}{d t}=\pi(1-\rho) N-\left(\frac{\beta I}{N}+\mu+\rho\right) S \\
& \frac{d E}{d t}=\frac{\beta I S}{N}-(\mu+\gamma) E \\
& \frac{d I}{d t}=\gamma E-(\mu+\varepsilon) I \\
& \frac{d R}{d t}=\varepsilon I+\rho S-\mu R
\end{aligned}
$$

2. Analisis kestabilan bilangan reproduksi dasar $R_{0}$ model SEIR pada penyebaran penyakit pneumonia pada balita dengan pengaruh vaksinasi di Kota Makassar diperoleh beberapa $R_{0}$, untuk simulasi yang dilakukan tanpa vaksinasi nilai $R_{0}$ besar dari satu berarti penyakit masih tetap ada dalam populasi sedangkan untuk simulasi yang dilakukan dengan vaksinasi $R_{0}$ kecil dari satu berarti penyakit akan menghilang dan tidak meluas dari populasi.

3. Jika tidak dilakukan vaksinasi maka nilai reproduksi dasar yang dihasilkan lebih dari 1 artinya penyakit akan selalu ada sampai waktu yang tidak terbatas, mengakibatkan populasi pada kelas exposed, infected dan recovered mengalami peningkatan, jika dilakukan vaksinasi sebesar $10 \%$ bilangan reproduksi yang dihasilkan lebih dari 1 , artinya vaksinasi yang dilakukan tidak berhasil membuat penyakit menghilang dari populasi, selanjutnya jika diberikan vaksinasi sebesar 50\% dan 90\% maka nilai reproduksi dasar yang dihasilkan kurang dari 1 artinya penyakit akan menghilang dan tidak meluas dari populasi dalam waktu tertentu. Semakin tinggi tingkat vaksinasi, penyakit akan menghilang dari populasi dalam waktu yang semakin cepat. Proporsi vaksinasi minimum untuk R sebesar $10 \%$ dari jumlah terinfeksi yaitu 0,35. untuk $\mathrm{R}$ sebesar 50\% dari jumlah terinfeksi yaitu 0,270, dan untuk $\mathrm{R}$ sebesar $90 \%$ dari jumlah terinfeksi adalah 0,21 artinya harus ada 35\%, 27\% dan $21 \%$ vaksin yang diberikan kepada seluruh balita yang rentan agar penyakit akan menghilang dan tidak meluas dari populasi

\section{DAFTAR PUSTAKA}

Ansar, A. (2018). Pemodelan Matematika SIRS dengan Vaksinasi pada penyebaran panyakit Malaria (Studi Kasus: Kabupaten Merauke) (Skripsi). Universitas Negeri Makassar, Makassar.

Depkes RI. (2002). Pharmaceutical Care Untuk Penyakit Infeksi Saluran Pernapasan, Departemen Kesehatan Republik Indonesia: Jakarta. 
Diekmann, O \& Heesterbeek. (2000). Mathematical Epidemilogy of Infectious Disease. New York: John Wiley and Son.

Ermilatni, E. (2016). Model Matematika SEIR untuk Kontrol campak dengan vaksinasi di Kabupaten Bulukumba (Skripsi). Universitas Negeri Makassar, Makassar.

Grimshaw, R. (1990). Nonlinear Ordinary Differential Equations. Blackwell Scientific Publication. Oxford Boston Melbourne

Ihsan, H., Side, S., Wulandari, E. (2020). Pemodelan Penggunaan E-Money Pada E-Parking Kota Makassar. Journal of Mathematics, Computations, and Statistics, 3(2). 88-96.

Lestari, D. (2013). Diktat Persamaan Diferensial.Universitas Negeri Yogyakarta, Yogyakarta.

Rosdiana. (2015). Pemodelan Matematika SIR dengan Vaksinasi ada Penyebaran Penyakit Hepatitis B (Studi Kasus Provinsi Sulawesi Selatan) (Skripsi). Universitas Negeri Makassar, Makassar.

Ruslaeni. (2010). Gambaran Kejadian Pneumonia Pada Bayi dan Balita di RSUD Labuang Baji Makassar Tahun 2009 (Skripsi). Universitas Islam Negeri (UIN) Alauddin Makassar, Makassar.

Syam, R., Side, S., \& Said, C.S. (2020. Model SEIRS Penyebaran Tuberkulosis di Kota Makassar. Journal of Mathematics, Computations, and Statistics,3(1). 11-19.

Side \& Rangkuti. (2015). Pemodelan Matematika dan Solusi Numerik untuk Penularan demam Berdarah. Medan: Perdana Publishing.

Side, S., Zaki ,A., \& Sari, N. (2018). Analisis Model Matematika Penyebaran Demam Berdarah Dengue dengan Fungsi Lyapunov. Journal of Mathematics, Computations, and Statistics, 1(2). $125-141$.

Sugiyarto. (2014). Persamaan Diferensial dilengkapi Contoh Penyelesaian Masalah untuk Umum dan Mahasiswa. Yogyakarta: Binafsi Publisher.

Wahab, W. \& Subiantoro, A. (2004). Fundamental of Control system Stability Criteria routhhurwi. 